\title{
As Mulheres e o Romantismo. A autocrítica de Ana Plácido
}

The Women and the Romanticism. Ana Plácido's self-critical

Fábio Mário da Silva

Universidade Federal do Sul e Sudeste do Pará, Brasil

famamario@gmail.com

Texto desenvolvido durante pós-doutoramento na área de Estudos Portugueses, com supervisão do Professor Doutor Ernesto Rodrigues, do CLEPUL, da Faculdade de Letras da Universidade de Lisboa.

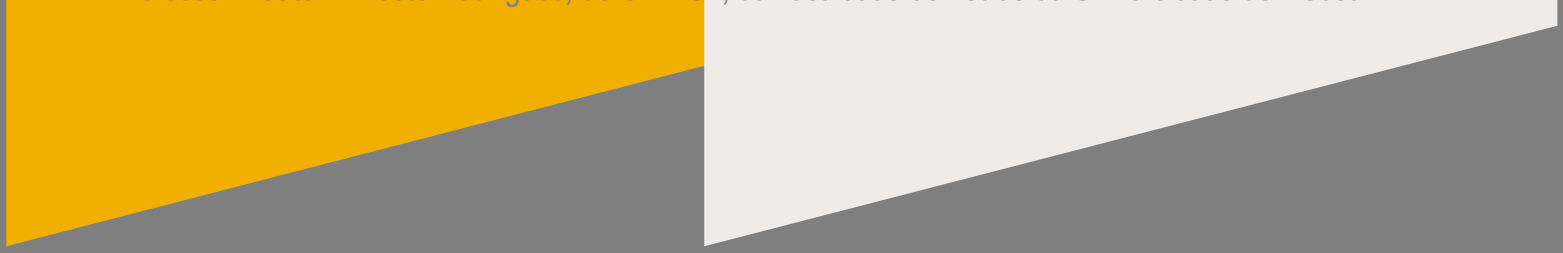

Conflito de interesses: nada a declarar. Financiamento: nada a declarar.

Data de Submissão: 05/05/2021

Data de Aprovação: 10/07/2021 


\section{Resumo}

A proposta do nosso trabalho é refletir como a estética romântica comparece na obra de Ana Plácido (1831-1895). Contudo, antes apresentaremos uma pequena reflexão sobre as teorias do Romantismo. Por fim, demonstraremos porque Ana Plácido, apesar de adotar em sua escrita esse estilo muito em voga no século XIX, acaba por tecer uma autocrítica a esse tipo de literatura, a qual estaria muito distante da realidade feminina na altura.

Palavras-chave: Ana Plácido, Romantismo, literatura portuguesa, condição feminina, mulheres.

\section{Abstract}

The purpose of this article is to reflect on how the romantic aesthetic appears in the work of Ana Plácido. First we present a brief overview on theories of Romanticism, before explaining why Ana Plácido who, despite adopting a style that was very much in vogue in the 19th century, ends up generating a self-critical assessment of this type of literature very distant from the female reality of her epoch.

Keywords: Ana Plácido, Romanticism, portuguese literature, female condicional, women. 
Os lexemas romantismo e romântico estão atrelados a uma série de concepções e ideias que vão desde estilos e tipos de narrativas até, por exemplo, pensamentos filosóficos, correntes artísticas e posicionamentos políticos - apesar de, originalmente, 0 adjetivo romantic estar associado às manifestações literárias (Aguiar e Silva, 1997, p. 482). Estes vocábulos se popularizaram no século XIX através da adoção intencional de artistas e escritores que viram no Romantismo uma maneira de entender a vida $\mathrm{e}$ a arte que, juntas, compreenderiam uma parte deste século de maneira muito peculiar: ${ }^{57}$

\section{O Romantismo manifestou-se em todos os domínios da cultura, da arte e do pensamento, porque representa, de modo global e sistêmico, uma revolta, uma contestação e uma refutação, em relação à modernidade burguesa e capitalista, produto da racionalidade filosófica, científica e técnica. (Aguiar e Silva, 1997, p. 482).}

Ou seja, segundo Aguiar e Silva, uma das principais contraposições dos escritores românticos é o revide contra as atitudes da burguesia que ascende ao poder no século $X I X .^{58}$ É também nessa linha de investigação que Adilson Cintelli chega à mesma conclusão, percebendo a disparidade entre o mundo ideal dos românticos e o mundo real da sociedade burguesa:

O choque entre o Eu e o mundo, a tensão irreconciliável entre uma sociedade cada vez mais afirmadora da divisão do trabalho

${ }^{57}$ Conferir o verbete de Vitor Manuel Aguiar e Silva intitulado "Romantismo", do Dicionário do Romantismo (1997), e a obra de Adilson Citelli, Romantismo (1986).

${ }^{58}$ Segundo Adilson Citell, "se a aristocracia havia acumulado séculos de dinheiro e cultura, a burguesia estava ainda na fase e do domínio do capital e o artista romântico incapaz de se ajustar, fraturado pelo desejo de buscar uma totalidade impossível, acaba provocando a aparição de uma série de temas vinculados à fuga da realidade. Daí a volta para o Eu, a intensificação do elemento subjetivo, ou a expansão rumo a um tempo medieval, ou algum exótico espaço oriental. Nessa mesma linha se sucedem temas como o da valorização da morte, a intensificação religiosa, a preferência pelo tom penumbrista da noite, a idealização de uma natureza regeneradora dos desajustes que o homem vive em sociedade (1986, p. 75-76).

Na obra de Ana Augusta Plácido (1831-1895), como mais veremos adiante, o embate contra a sociedade burguesa, representada geralmente pelas personagens masculinas, tem uma função evidente na defesa das mulheres. Lembremo-nos que Ana Plácido era uma mulher que escrevia compulsivamente, ${ }^{59}$ dedicou-se em distintos períodos de sua vida a produção de vários gêneros literários, desde poemas, contos, meditações, crônicas e dramas até cartas, diário e romances.

de encher as burras, de ouvir o som da moeda e sofisticar as formas de poder e dominação" (1986, p. 84).

59 Segundo Maria Amélia Campos: "como era hábito de Ana, escrevia em qualquer papel que apanhasse pela frente" (2008, p. 207). 
Estreou com Luz coada por ferros ${ }^{60}$ em 1863, ${ }^{61}$ sendo que muitos dos textos dessa obra foram escritos durante o seu segundo período de encarceramento, em $1860 .{ }^{62}$

Contudo, antes de analisarmos passagens da obra de Plácido, é preciso referir que, em relação ao século XIX, Videira Lopes observara que é como musa ou personagem central, mais do que como autora, que a mulher aparece com destaque na literatura oitocentista (1997, p. 325). Realmente, se pensarmos na inserção das mulheres como produtoras de cultura no universo do espírito romântico europeu, ${ }^{63}$ encontramos suas presenças mais como personagens/modelos ficcionais, sejam de obras pictóricas ou literárias, do que como autoras. Apenas como exemplificação, tomemos como exemplo uma das principais referências da pintura portuguesa desse período, "Só Deus!", de 1856, de Francisco Augusto Metrass:

\footnotetext{
${ }^{60} \mathrm{~A}$ inspiração para o título da obra na qual estão inseridas as "Meditações", segundo Alberto Pimentel, foi retirada duma passagem do livro de Camilo Castelo Branco: "Este título, o mesmo que D. Anna Placido deu ao seu livro, publicado em 1863, pertence a Camilo, foi por Ella colhido n'uma nota ao Amor de Perdição. Diz a Nota: 'este romance foi escripto n'um dos cubiculos-carceres da Relação do Porto, a uma luz coada por ferros, e abafada pelas sombras das abobadas"' (Pimentel, 1899, p. 293).Contudo, como a primeira obra de Ana Plácido, Luz coada por ferros, foi, por um lado, publicada simultaneamente e escrita no mesmo período de cárcere que Camilo, e, por outro, quase todas as narrativas de Plácido focam em demasia o tema luz versus trevas, pensamos que talvez o próprio Camilo tivesse se inspirado nos textos de Ana, visto que tal temática aparece com frequência também na obra do escritor. (cf, Silva, 2020, p.137). ${ }^{61}$ A obra teria sido publicada em 1863 e teve recensões crítica imediatas da Revista Contemporânea de Portugal e Brasil (Alonso, 2014, p. 58). Luz coada por ferros teve uma segunda reedição em 1904.

${ }^{62}$ Ana Plácido passa cinco semanas num convento em Braga, de 27 de junho a 3 de agosto de 1859, aconselhada por influência do marido traído, Pinheiro Alves, e dos seus amigos, para, num segundo momento, ficar presa dezesseis meses na cadeia do
}

Porto, de 6 de janeiro de 1860 a 17 de outubro de 1861, à espera do julgamento de acusação de adultério. Foi absolvida em outubro de 1861. Depois disso, passa uma terceira fase encarcerada num convento em Lisboa, entre março e agosto de 1862 (Campos, 2008, p. 177; Alonso, 2014, p. 39-41).

${ }^{63}$ Como uma breve definição do conceito de romantismo, Adilson Citelli assim refere esse movimento estético nas artes europeias: "O romantismo foi mais que um programa de ação de um grupo de poetas, romancistas, filósofos ou músicos. Tratou-se de um movimento onde se abrigaram o conservadorismo e o desejo libertário, a inovação formal e a repetição de fórmulas consagradas, o namoro com o poder e a revolta radical: enfim, um conjunto tão díspare de tendências que seria ociosa bobagem inconseqüente mascarar através de generalizações apresentadas a riqueza e a diversidade que norteiam o movimento romântico. Talvez fosse possível pensar, num esforço didático, que 0 romantismo foi marcado por algumas preocupações recorrentes, às quais poderíamos aliar um certo anticlassicismo, uma visão individualista, um desejo de romper com a normatividade e com os excessos do racionalismo. Liberdade, paixão e emoção constituem um tripé sobre o qual se assenta boa parte do romantismo." (1986, p. 9). 


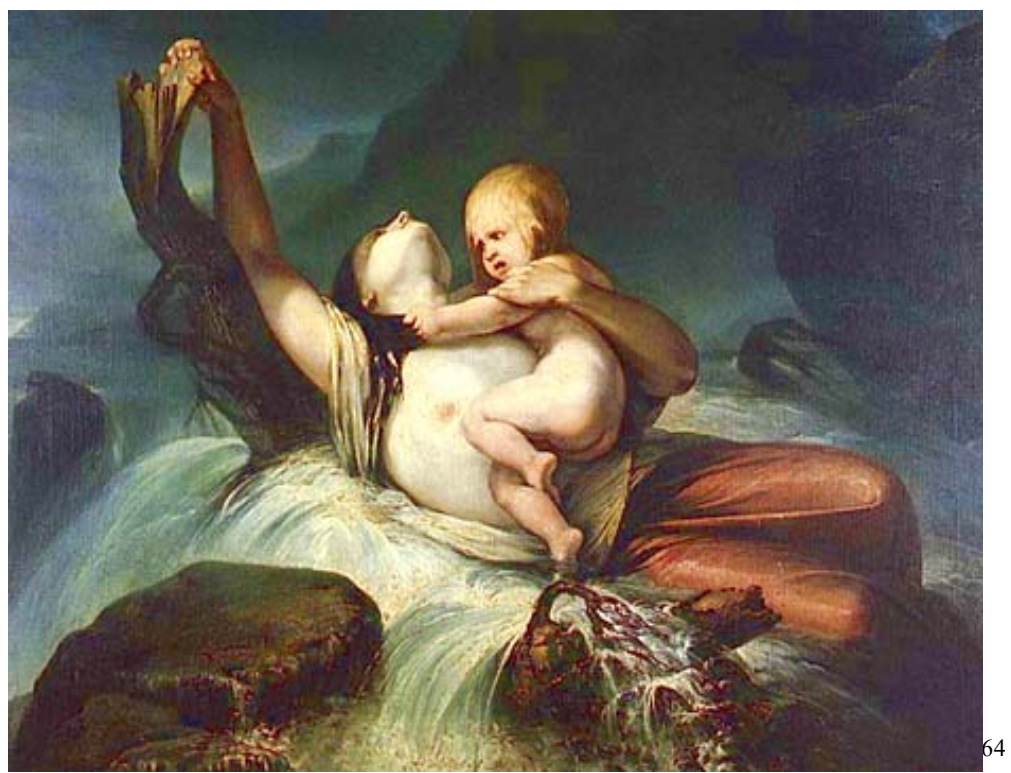

A focalização na imagem dramática da figura feminina - na brancura do seu corpo, a palidez como requisito de beleza, numa espécie de idealização - é uma caracterização muito comum às heroínas românticas, e a sua postura austera, com o seio à mostra, contrasta com o horror do rosto da criança, através de uma cena que alude tanto à exacerbação dos sentimentos trágicos, como a um cenário inóspito de tormenta e de declínio para a morte (nomeadamente por meio do abismo implícito na pintura). ${ }^{65} \mathrm{~A}$ alusão à morte está imbuída na pintura através da tragicidade e do melodrama. Por isso, segundo Maria Aires Silveira, encontramos em "Só Deus!" um:

\section{espírito melodramático, patente no movimento da torrente, nos ramos retorcidos de velhos troncos, na mão que se firma no madeiro, nas carnações do corpo da mulher e pernas da criança, ou na sua expressão de pavor, envolve a totalidade destes expedientes sentimentalistas de}

um desespero maternalmente humanizado. (2010, s. d). ${ }^{66}$

As mulheres (heroínas românticas ou os heróis românticos) clamam, muitas vezes, por uma salvação, independentemente dos seus motivos e dos sofrimentos. Porém, em outros casos, essas heroínas/heróis veem a morte como a libertação de um mundo injusto e que não thes compreende. Assim, o próprio título da obra de Metrass alude a um outro aspecto presente nas obras do período romântico, a religiosidade, através da exclamativa "Só Deus!", pois só por intervenção divina poderia se salvar mãe e filho de um fim trágico. 0 título do quadro poderia ser também uma alusão ao fato de que só Deus compreende o ser humano, trágico e em constante sofrimento, dentro do contexto romântico.

Lembremo-nos que, tanto na literatura quanto na pintura romântica, a relação com a paisagem, com a natureza (o meio circundante), apresenta-se através de um clima melancólico, de tons sombrios e tétricos, relações essas que, mais adiante, apontaremos

\footnotetext{
${ }^{64}$ Conferir: Museu Nacional de Arte Contemporânea do Chiado: http://www.museuartecontemporanea.gov.pt/pt/pecas/ver/397/artist.

65 Segundo Adilson Citelli, é comum encontrarmos nas pinturas românticas oitocentistas "a presença de regiões inóspitas, muitas vezes voltadas ao distante Oriente, o ritmo do sonho, da fantasmagoria e do mistério são constantes em obras de pintores românticos". (1986, p. 26).

66 Acesso ao texto diretamente no Museu Nacional de Arte Contemporânea do Chiado:
} http://www.museuartecontemporanea.gov.pt/pt/pecas/ver/397/artist. 
nas narrativas de Ana Plácido. Na pintura de Metrass, a correnteza representa a força da natureza que, exuberante, aparenta ser 0 fim mortal da mãe e filho, além do resgate da tradição romântica europeia da associação da imagem da mulher com a água, ${ }^{67}$ tal como a "Ofélia" de Mullais (cf. Walther, 1999, p. 87), que aponta para o sofrimento humano, outro grande tropos dessa estética.

Ora, apesar de não fazer parte de uma corrente literária exclusiva, oscilando entre traços românticos e clássicos, a obra de Ana Plácido atravessa várias dessas características do quadro de Metrass, do dito estilo romântico, e é sobre esses aspectos presentes em sua escrita que iremos refletir na próxima rubrica, sem esquecer, no entanto, de demonstrar como a autora tece críticas ao próprio estilo que passa a adotar em seus textos.

\section{Ana Plácido e o Romantismo}

Lembremo-nos que Ana Plácido foi uma mulher à frente do seu tempo, principalmente pela ousadia de enfrentar as figuras patriarcais e de imposição social. Ana foi casada forçosamente com Manuel Pinheiro Alves, por pressão direta do pai, José Plácido Braga, em 28 de setembro de 1850 , no dia seguinte aos seus dezenove anos, mantendo durante anos uma relação clandestina com o escritor Camilo Castelo Branco, razão por que ambos foram presos, processados e, depois, absolvidos. Sobre a celebração do casamento de Ana Plácido com Pinheiro Alves, Manuel Teles assim nos dá as informações:

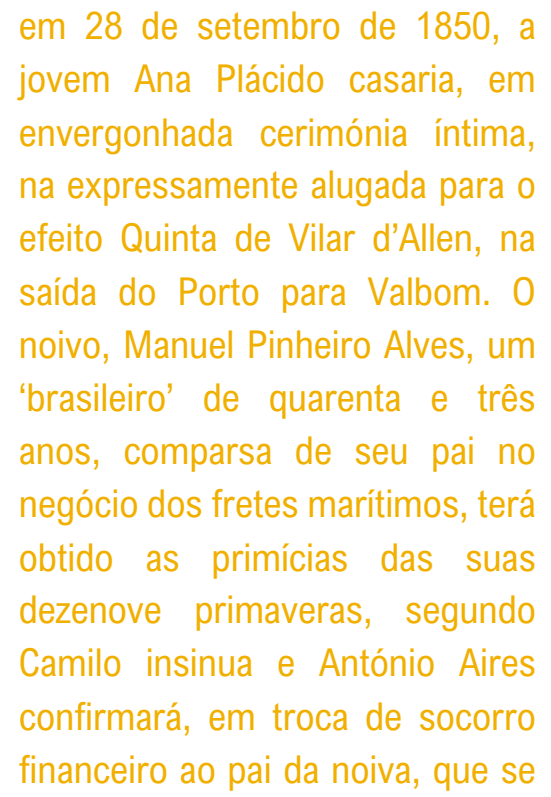

67 Gaston Bachelard associa, em A Água e os Sonhos: ensaios sobre a imaginação da matéria, a figura feminina às características da água, pois ela é um símbolo da origem da

\section{encontraria em grandes embaraços financeiros. (2008, p.} 49).

Após a morte do marido, o filho legítimo, Manuel Plácido, herda a fortuna do pai e será Ana a administrar os bens, período em que passa a conviver abertamente em sociedade com o seu amante, que se tornará futuramente o seu marido, porquanto se casará com Camilo em 9 de março de 1888. Além destes fatos biográficos, como bem atenta Aníbal Pinto de Castro, Ana Plácido é uma mulher invulgar para sua época, visto que a sua formação (cultural e literária) era pouco comum, mesmo para mulheres da mais alta posição social: "qualquer leitor da sua obra não pode deixar de notar a presença que nela assume esse cabedal de cultura literária, patenteado em epígrafes, citações ou sob outras formas de apropriação intertextual, que envolviam variados escritores" (1995, p. 4).

E sobre essa apropriação intertextual de que fala Castro, Júlio Cesar Machado refere, no prefácio à primeira edição de Luz coada por ferros, de 1863, que a preferência de Ana Plácido é por "leituras graves", - ou seja, de formação cultural greco-romana, livros eclesiásticos, clássicos portugueses, Camões,

criação, sendo ela mãe, natureza, útero, fonte de vida (o leite materno) e de morte, associada a fontes de prazer e aos banhos como limpeza do corpo (cf. Bachelard, 1997, p. 89-140). 
Gil Vicente - e tenta convencê-la a despertar para a chamada "literatura fácil", aquela que 0 "espírito humano tem produzido de mais agradável" (2015, p. VI): os romances de George Sand; os folhetins de Julio Janin; as obras de Dumas pai e Dumas filho; os romances de Camilo; Garrett com Viagens na Minha Terra e Folhas Caídas (livro de versos citados várias vezes em diferentes narrativas da autora). Tal estratégia acaba por dar certo, porque Ana Plácido acaba por "aceitar" ou "introjetar", em parte, a dita literatura romântica, como forma e conteúdo, mas não deixando de criticá-la, como mais adiante veremos, porque vê nela um modelo que não é vantajoso para as mulheres.

Evidentemente, o próprio Camilo Castelo Branco acaba por ser o grande incentivador do seu trabalho literário, pelo menos nos primeiros anos da carreira literária de Ana, visto que anos mais tarde acaba por não continuar incentivando o trabalho da amada. Observa-se, por exemplo, as várias epígrafes das obras de Camilo nos textos de Ana Plácido, bem como as dedicatórias que Camilo deixa em vários textos a Ana Plácido sob o criptônimo de "Raquel", inspirando-se na relação amorosa com ela para produzir muitos dos seus romances, inclusive Amor de Perdição. Lembremo-nos que Raquel ${ }^{68}$ também é título de um texto de Ana Plácido.

Segundo Aníbal Pinto de Castro, ao lermos a obra de Ana Plácido, no seu conjunto, é fácil perceber que estamos diante de um projeto acabado, ainda que longe da perfeição, do romantismo português:

Não só os seus principais traços definidores, porque feitos de clichês, se apresentam facilmente redutíveis ao esquematismo dos paradigmas, como, por outro lado, inculcam ao leitor, numa perspectiva feminina (e por vezes

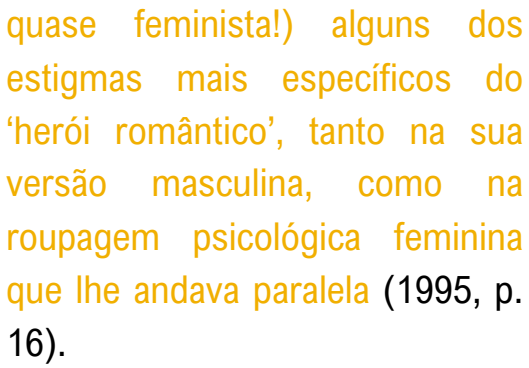

Realmente, podemos encontrar em muitos textos de Ana Plácido esquemas narrativos e caracterização de personagens que se aproximam do modelo romântico, mas com objetivos, segundo Maria Eduarda Borges dos Santos, de "oferecerem ensinamentos concretos, advertências sérias relativamente às decisões amorosas das jovens portuguesas" (2011, p. 303).

Por exemplo, quando escreve "Às portas da eternidade", conto publicado em Luz coada por ferros (1863), Ana Plácido tem em mente o modelo goethiano da técnica narrativa e a temática do suicídio, que passa pelo "desejo de morrer", como resultado inevitável e única forma de sanar a dor da infelicidade amorosa. A autora assim trabalha dentro de uma das perspectivas de caracterização do texto romântico, a focalização e aclamação da morte, como fuga do sujeito melancólico:

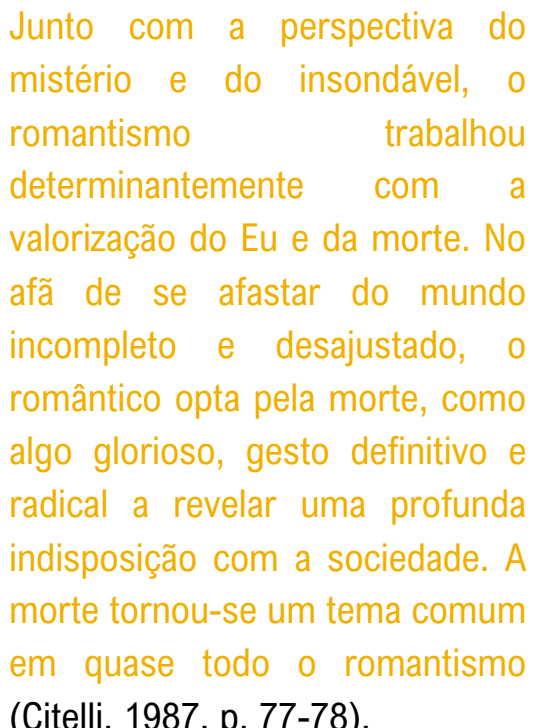

(Citelli, 1987, p. 77-78).

${ }^{68}$ Texto intitulado "Três lágrimas de Raquel", publicado n'O Civilizador, Porto, n. ${ }^{\circ} 11$, p. 108-109. 
Relembremo-nos também que "Às portas da eternidade" inicia a sua diegese com a descrição da paisagem e clima vistos da janela do segundo andar por uma mulher vestida de luto. A personagem não é nomeada e o texto revela a relação entre as paisagens da natureza e o estado emocional da protagonista, cuja descrição aparenta dar a tônica a um discurso de acordo com o qual aquilo o que se avista não é apenas um cenário natural, mas uma projeção de si mesma, sua imagem num espelho. Neste trecho, deparamo-nos com 0 esquema romântico em que, por correlatividade, a descrição da natureza apresenta o sujeito da ação e, a seguir, reflete as suas afetações (cf. Silva, 2020, p. 79). Esse esquema também vamos encontrar no conto "O Amor...!", aquando da primeira troca de olhares entre o sedutor Manuel da Cunha e a protagonista Paula, encontro que aconteceu no vão da janela da casa de Paula, com uma descrição tipicamente romântica e na qual 0 clima reflete já as futuras afetações trágicas que recairão sobre a protagonista: "Foi n'uma d'estas tardes de novembro, negra e temerosa, que os seus olhos se encontraram com os de Manuel da Cunha" (1995, p. 121). No fim das duas narrativas, encontramos um suicídio atrelado a falta de correspondência amorosa, em "Às portas da eternidade"; e um devido ao estado de loucura, na narrativa "O Amor...!". A grande problemática dessas heroínas placidianas românticas é, como bem atenta Maria Eduarda Borges dos Santos, a questão do enfrentamento (profundamente romântico) entre o mundo real e o mundo ideal:

Durante o período romântico, a ilusão, que parecia vital, convertese em armadilha construída pelo sujeito, na medida em que o verdadeiro nunca é real, ou seja, enquanto a realidade é, por definição, independente do homem, a verdade pertence à ordem do discurso ou da representação que é toda a arte. Daqui o desajuste sentido pelo indivíduo romântico entre 0 mundo ideal e o mundo real, a falta de correspondência entre 0 primeiro, fornecido pela literatura, e o segundo, pela vida, que raramente constitui 'prova' daquele. (2011, p. 277-278)

É exatamente este conflito operado entre 0 mundo real e o mundo ideal que será refletido pela protagonista Diana, do romance Herança de Lágrimas. Diana, levada por estímulos de uma vida sem esperanças, e de uma alma inquieta, passa estudar o amor através de diversas leituras de obras consagradas, desde os clássicos até romances do romantismo europeu:

Essa paixão sublime que aniquila ou engrandece, nos romances da época. Achei, porém, fastiosas as descrições, e algumas enjoativamente imitadas. Ou o espiritualismo piegas sem aquele cambiante admirável do Raphaël, de Lamartine; ou a sordidez da matéria tressuando no arredondado das formas e das galanices do estilo.

Não era isto o que eu imaginava. Tentei ir mais longe à cata de modelos; quis conhecer as tragédias de grandes mestres literários de passadas eras. Aí sim: admirei os tipos grandiosos das Julietas, Desdemonas, e Kitty Bell; mas nem compenetrando-me do fogo dessas labaredas fundidas em bronze encontrei o mito que devia tornar o combustível o mármore da minha essência (2019, p. 18).

Ao referir desde personagens da literatura 
grega, passando por Shakespeare até um romance semi-biográfico de Lamartine, um dos autores mais influentes do romantismo francês e de circulação e influência em vários países, Ana Plácido vai delineando a associação entre o amor e a literatura romântica. Por isso, a protagonista também vai referir à amiga Henriqueta o seu desejo de se matar, devido à desilusão amorosa com o casamento - outra heroína placidiana que alude ao suicídio -, ato que a faz desistir em razão de sua religiosidade:

Confesso-to: tenta-me muito a ideia do suicídio, sorri-me o aniquilamento;

tenho constantemente diante dos olhos este farol luminoso a chamar-me ao porto desejado; mas, no maior ardor da luta, levanta-se invulnerável no meu peito a muralha do cristianismo; os meus olhos volvem-se à cruz sublime, que me está dizendo: sê forte (2019, p. 25).

Por isso, mais à frente, a personagem Diana diz que passou a estudar e conhecer um outro tipo de amor, o sublime de Cristo, e por isso começou a estudar, meditar a religião do "Divino Mártir". A personagem vai discorrendo, nessa sua epístola à amiga Henriqueta, que, na realidade, 0 "ideal nada se parece com 0 ideal dos poetas. 0 ideal deles é uma imagem criada aos vapores nevoentos da imaginação escandecida pelos ardores imperiosos da mocidade" (2019, p. 19). Daí a protagonista emitir a sua opinião sobre os perigos da literatura romântica que entra em choque com a realidade vivida pelas mulheres e, para isso, usa como exemplo um autor português muito lido e até hoje canônico, Almeida Garrett, ${ }^{69} \mathrm{com}$ Folhas Caídas,

Pobre mulheres! Eu dizia a todas: fugi do poeta, do inspirado, do

69 Garrett torna-se, durante o século XIX, uma referência importante de literatura, principalmente com a publicação de

\begin{abstract}
chamado homem de coração. Tudo isso são palavras ruidosas, laços que prendem eternamente almas impressionáveis. Ele, o poeta, não pode gastar o gênio num só amor. 0 exclusivismo é para estupidez feliz que se contenta com pouco. Os bemfadados de Deus têm de cantar as Evas antes e depois do pecado, as tempestades procelosas da vida, os desenganos do mundo, as desesperanças da terra, e as magnificências do céu (Plácido, 2019, p. 20).
\end{abstract}

A personagem Diana vê na ilusão do amor, nos versos escritos pelos poetas, os chamados "homens de coração", palavras ilusórias que fogem, efetivamente, à realidade vivida pelas mulheres. Por isso, Maria Eduarda Borges dos Santos chega à seguinte conclusão:

Se, para Ana Plácido, a prática da leitura era uma forma incontestável de enriquecimento cultural, a escritora romântica distingue claramente a leitura que contribui para a edificação de um caráter forte e heróico, da que conduz às esferas enganadoras do ideal e que está na origem de compleições psicológicas onde a força da imaginação, desligada do real, tem papel preponderante. Neste sentido, se privilegia os autores clássicos, não deixando embora de expressar admiração por escritores modernos em que a edificação do cristianismo constitua a finalidade primordial, é também capaz de advertir as suas leitoras para o caráter ilusório de certa literatura mais sentimental,

Viagens na Minha Terra e Folhas Caídas, obras que serão expoentes máximos da literatura romântica portuguesa. 
realçando os seus efeitos nefastos (Santos, 2011, p. 368).

Outra personagem placidiana de Herança de Lágrimas que representa a típica personagem de cariz oitocentista romântico é Nuno d'Alvarães, por quem a protagonista vai se apaixonar. Nuno é apresentado por sua irmã, Beatriz, à Diana da seguinte maneira: "Tenho ainda um irmão, um verdadeiro coração de poeta, um desgraçado que vive de quimeras, $e$ que não posso roubar com todo o meu carinho não sei o que sestro infeliz que the cava abismos em toda a parte" (2019, p. 34). Esta descrição é típica de personagem melancólica e insatisfeita com o mundo, com uma "alma irrequieta", queixosa e desassossegada, por isso, como vamos observar mais à frente na diegese, essa personagem, diante de algumas decepções, sugere o suicídio como meio para curar o seu sofrimento. Nuno, segundo confessa Beatriz à Diana, se apaixona muito rápido e sucumbe a esses mesmos sentimentos não correspondidos: "me convenci de que isto de amor nele é uma doença, uma monomania que só o tempo háde curar" (2019, p. 51). As paixões, dentro desse modelo oitocentista, são despertadas por um simples olhar e o enamoramento dá-se de maneira abrupta, como bem revela Nuno à protagonista: "Bastou-me vê-la, não precisei de tratá-la de perto para descobrir as qualidades que valem este amor tão desinteressado quanto infeliz" (2019, p. 75).

Isto porque o amor, como aspecto do sentimento exacerbado do ser enamorado, é, para as personagens do romantismo oitocentista, a representação de um ideal sublime, como bem confessa Diana: "0 amor representava-se-me absoluto, é verdade, mas de um absolutismo todo ideal, sem sombra de mácula ou torpeza" (2019, p. 75). Contudo, a narrativa relembra a estória de vida da mãe de Dina, D. Branca, como ela se apaixonou por Rodrigo, depois que se casara a pedido do pai com D. Jorge de Melo. Branca se apaixona pela primeira vez quando vê Rodrigo, sem saber 0 seu nome ou qualquer informação de sua vida, numa cena assim descrita, quando foi a uma Ioja com seus lacaios: "por casualidade, ou atraído(sic) por magnético fluido, os olhos dela encontraram-se com os do desconhecido" (2019, p. 125). A troca de olhares e paixão fulminantes terão sido recíprocas, mas o que mais adiante veremos é que Rodrigo, passa a manter relações com outras mulheres, afinal se enfastiara de Branca, quando essa é expulsa de casa por seu marido, chegando à conclusão de que não a amava. Por isso, para Fernando Damas Cabral, nesse romance, Ana Plácido defende "Diana e todas as mulheres que ela simboliza alegoricamente" (1991, p. 33), isto é, as mulheres que são enganadas e exploradas por falsas paixões e por casamentos infelizes. Ou seja, o amor e/ou a paixão podem ser deveras ilusórios e, geralmente, nas narrativas de Ana Plácido, são os homens que se cansam rapidamente, após terem consumado 0 ato sexual com as "amadas". Por isso, o final do romance Herança de Lágrimas trata do tema como uma efemeridade passageira: "O amor é o átomo que gira um momento; é um raio de sol que se perde no espaço para sempre" (2019, p. 204).

Essas relações amorosas impossíveis são, segundo Michelle Perrot, comuns no século XIX, porque é fácil encontrar, pelo menos no contexto francês, muitos processos contra casos amorosos inadequados, fatos que se contrapõem ao amor descrito na literatura romântica que tem de enfrentar a realidade dos interesses particulares de funcionamento da família burguesa:

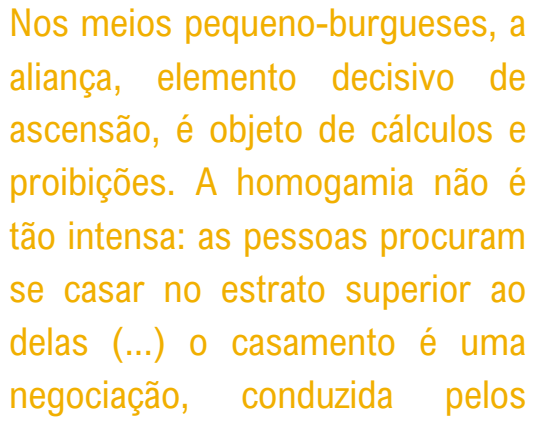
aliança, elemento decisivo de ascensão, é objeto de cálculos e proibições. A homogamia não é tão intensa: as pessoas procuram se casar no estrato superior ao negociação, conduzida pelos 
parentes (as tias casamenteiras), os amigos, pelos próximos (o padre) e todos os seus fatores devem ser avaliados (...). Mas as estratégias matrimoniais se diversificam e se tornam complexas. 0 dinheiro assume formas variadas: móveis, imóveis, negócios e "esperanças". Outros elementos entram em linha de conta: o nome, a consideração, a "situação" (as profissões liberais gozam de grande estima), a "classe" e a beleza fazem parte dos termos de troca (2009, p. 123-124).

É exatamente contra esse papel do seio familiar burguês, de imposição do matrimônio, que a literatura de Ana Plácido se opõe, e por isso a inadequação entre 0 mundo romântico $e$ idealizado do amor oitocentista e a dura realidade social por que passam as mulheres. A autora faz essa associação descumprindo o padrão canônico da família como expressão dos sentimentos e base de felicidade individual, noção associada ao imaginário burguês da vida privada oitocentista, e tenta não cumprir alguns linhas basilares de um certo tipo de literatura da altura:

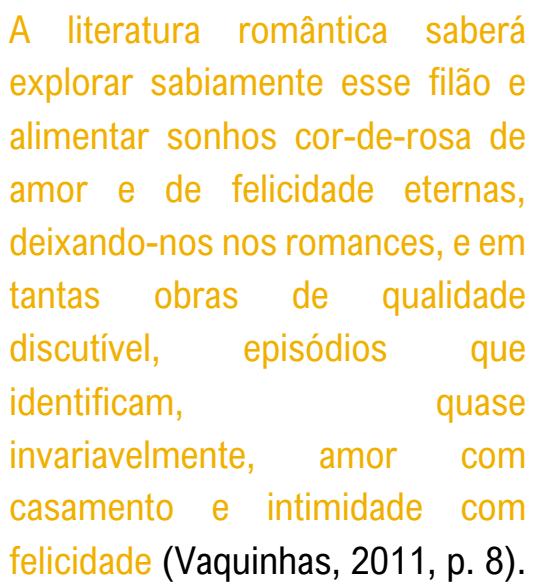

Na ficção de Ana Plácido, as ideias de amor eterno e desse "mundo cor-de-rosa" praticamente não existem, isso porque as bases com que são erguidos os casamentos burgueses não podem associar-se a esse modelo. Afinal, o que esse sistema social busca, para a sua narrativa, não é a valorização dos sentimentos e das relações afetivas, mas a manutenção e acumulação de riquezas e de bens simbólicos, aumentando o prestígio social, cujo paradigma pode, muitas vezes, estar na contramão da construção de um enlace matrimonial a partir do afeto sincero.

\section{Possíveïs Conclusões}

Segundo Hilary Owen e Cláudia Pazos Alonso (2011, p. 19-20), é recorrente o fenômeno de não inclusão de mulheres escritoras nas histórias literárias devido à dificuldade em relacioná-las com escolas, grupos ou correntes literárias. Ora, é evidente que Ana Plácido escreve dentro dos parâmetros da literatura dita romântica, apesar de criticá-la, mas tais características, prementes em sua obra, não fizeram com que o seu nome aparecesse com algum destaque nas ditas histórias literárias. Apesar disto, não queremos dizer que Ana Plácido era uma escritora "puramente" romântica, visto que podemos encontrar muitas características e estilos em sua obra, devido a um leque de leituras feitas pela autora, principalmente de literatura clássica.

Sabemos que, durante o Romantismo, o amor idealizado traduzia o problema da chamada "fuga da realidade", isto quer dizer: "afasta-se do conceito de realização amorosa na medida em que, para ele, o sentimento do amor é algo bom, puro, impossível, portanto, de ser realizado num mundo desagregado, inaceitável" (Citelli, 1986, p. 81). Ora, na obra de Ana Plácido a desilusão não acontece devido 
apenas ao enfrentamento do mundo real burguês com a evasão amorosa platônica, isso porque Ana Plácido denuncia a subjugação das mulheres a esse sistema baseado em poder financeiro, e também legislativo e moral, modelo para o qual não há possibilidade de simetria amorosa, pois nele deve prevalecer 0 amor masculino em detrimento do feminino.

Por isso, há de notar que, em sua literatura, quase sempre todas as heroínas sucumbem, morrem ou terminam infelizes nos finais das narrativas, porque o universo romântico, isto quer dizer, a realidade ficcional, não comporta a realidade factual, da sociedade que Ana Plácido critica, e que tanto a condenou, devido ao escândalo de adultério por que passou, juntamente com Camilo Castelo Branco.

Mesmo adotando o estilo de escrita do romantismo europeu, Plácido se nega a escrever 0 final de suas narrativas com 0 "felizes para sempre", porque, para a escritora, isso é uma falácia. Daí o caráter mais subversivo de sua escrita, de denunciar às (aos) suas (seus) leitoras (leitores) os enlaces amorosos mantidos apenas para as relações sociais, demonstrando a sua atenta visão sobre a sociedade da época, a partir da condição feminina e do contexto cultural do romantismo europeu.

Sabemos que Camilo Castelo Branco também, apesar de adotar a escrita ficcional romântica em muitas de suas obras, tem uma visão muito crítica da burguesia, do seu estilo de vida e da literatura romântica, mas o que diferencia a sua proposta da de Ana Plácido é justamente a defesa da condição feminina feita por Ana: a sua autocrítica em relação ao Romantismo parte de uma visão alterirária que quer partilhar com as mulheres, através de ficção de denúncia, os efeitos nocivos de uma realidade que não colabora para a construção da igualdade dos direitos femininos. 

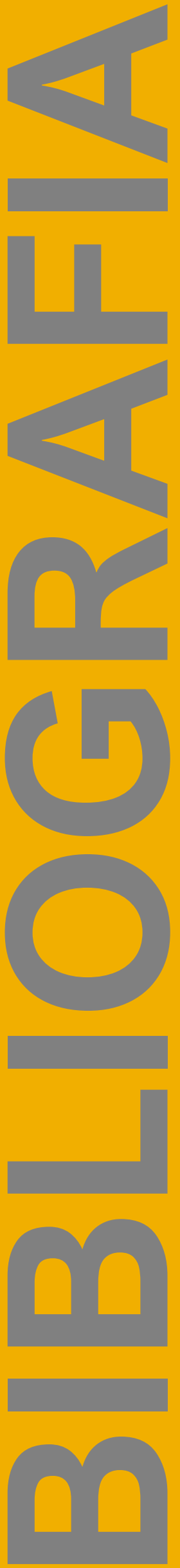

AGUIAR E SILVA, Vitor Manuel. Romantismo. In BUESCU, Helena Carvalhão (coord.). Dicionário do Romantismo Literário Português. Lisboa: Caminho, 1997, p. 487-492.

BACHELARD, Gaston. A água e os sonhos: ensaio sobre a imaginação da matéria. Tradução de Antônio de Pádua Danesi. São Paulo: Martins Fontes, 1997.

CABRAL, Fernanda Damas. Ana Plácido. Estudo, cronologia, antologia (narrativa). Lisboa: Caminho, 1991.

CAMPOS, Maria Amélia. Ana, a Lúcida. Biografia de Ana Plácido. Lisboa: Parceria A.M. Pereira, 2008.

CASTRO, Aníbal Pinto de. Ana Plácido a mulher que se maravilhou a si própria. In PLÁCIDO, Ana. Luz coada por ferros/ Herança de Lágrimas. Edição facsimilada. Vila Nova de Famalicão: Lello \& Irmãos Editores/ Câmara Municipal de Vila Nova de Famalicão, 1995, p. 3-31.

CITELLI, Adilson. Romantismo. São Paulo: Editora Ática, 1986.

LOPES, Videira G. (A) mulher (e a literatura do século XIX). In BUESCU, Helena Carvalhão (coord.). Dicionário do Romantismo Literário Português. Lisboa: Caminho, 1997.

MACHADO, Julio Cesar. Introdução. In PLÁCIDO, Ana. Luz coada por ferros. Edição fac-similada no âmbito das comemorações do $1 .{ }^{\circ}$ Centenário da morte de D. Ana Augusta Plácido. Vila Nova de Famalicão: Lelo \& Irmão Editores \& Câmara Municipal de Vila Nova de Famalicão, 2015, p. VI-XV. OWEN, Hilary; PAZOS ALONSO, Cláudia. Antigone's Daughters? Gender, Genealogy, and the Politics of Authorship in 20th-Century Portuguesa Women's Writing. Lewsiburg: Bucknell Press, 2001.

PLÁCIDO, Ana. Herança de Lágrimas. Prefácio de Inês Pedrosa. Lisboa: Sibila Publicações, 2009.

PLÁCIDO, Ana. Luz coada por ferros. Edição fac-similada no âmbito das comemorações do $1 .{ }^{\circ}$ Centenário da morte de D. Ana Augusta Plácido. Vila Nova de Famalicão: Lelo \& Irmão Editores \& Câmara Municipal de Vila Nova de Famalicão, 2015.

PERROT, Michelle. Figuras e papéis. In ARIÈS, Philippe; DUBY, Georges (dir.); PERROT, Michelle (org.). História da Vida Privada. Da Revolução Francesa à Primeira Guerra. Tradução de Denise Bottmann e Bernardo Joffily. São Paulo: Companhia de Bolsa, 2009, p. 107-168.

SANTOS, Maria Eduarda Borges dos. Da identidade feminina na ficção portuguesa de

Oitocentos: voz(es) de mulher, perspectiva (s) de autor. Tese de doutoramento.

Salamanca: Universidade de Salamanca, 2011.

SILVA, Fabio Mario. 0 suicídio enquanto topos romântico na narrativa "Às portas da eternidade", de Ana Plácido. In Revista Entheoria. Vol. 7. N. ${ }^{\circ}$ 1. UFRPE: Serra Talhada, 2020, p. 76-86. Disponível em $\langle$ http://www.journals.ufrpe.br/index.php/entheoria/article/view/3683 $>$.

Acesso em 7 de setembro de 2020. 
SILVEIRA, Maria Aires. Só Deus! 1856, Francisco Metrass. In Museu Nacional de Arte Contemporânea do Chiado. Disponivel em $<$ http://www.museuartecontemporanea.gov.pt/pt/pecas/ver/397/artist $>$ Acesso em 24 de julho de 2020.

TELES, Manuel Tavares. Camilo e Ana Plácido. Episódios ignorados da célebre paixão romântica. Porto: Edições Caixotim, 2008.

WALTHER, Ingo F. (edit.). A pintura da Era Romântica. Época e Estilos. Trad. Luísa Rodrigues. Lisboa: Taschen, 1999.

VAQUINHAS Irene. Introdução. In MATTOSO, José; VAQUINHAS Irene. História da Vida Privada em Portugal. A Época Contemporânea. Lisboa: Círculo de Leitores, e Temas e Debates, 2011, p. 6-20. 